\title{
Expression of Anthocyanins in Callus Cultures of Cranberry (Vaccinium macrocarpon Ait)
}

\author{
D.L. MADHAVI, M.A.L. SMITH, and M.D. BERBER-JIMÉNEZ
}

\begin{abstract}
Expression of anthocyanins and other flavonoids in callus cultures established from different parts of cranberry plant was investigated and the effect of explant source on the in vitro product was determined. Callus cultures were initiated from different parts of the plant in a modificd Gamborg's medium with $5.37 \mu \mathrm{M} \alpha$-naphthalencacetic acid, 0.45 $\mu \mathrm{M} 2,4$-dichlorophenoxyacetic acid, and $2.32 \mu \mathrm{M}$ kinetin in the dark at $25^{\circ} \mathrm{C}$. Callus cultures accumulated anthocyanins only on exposure to light and maximum concentration was observed by day 12 . The cultures had lower levels of anthocyanins and only cyanidin 3-galactoside, cyanidin 3-glucoside, and cyanidin 3-arabinoside were identified in all cultures regardless of source of explant. Proanthocyanidin accumulation in cultures was independent of light, and levels were higher than in mature fruit. Exposure to light induced accumulation of flavonols and enhanced activity of phenylalanine ammonia-lyase in the cultures.
\end{abstract}

Key Words: anthocyanins, cranberry, callus, cyanidin

\section{INTRODUCTION}

THE CHARACTERISTIC bright red anthocyanin pigments in cranberries (Vaccinium macrocarpon Ait) make them an attractive potential source for natural food colors. Consumer demand for natural products has prompted new research on development of cell culture resources for pigment extraction. In vitro culture of highly pigmented genotypes may circumvent seasonal and geographic restrictions of cranberry crop production, and result in more product uniformity (Ilker, 1987; Shuler et al.; 1990; Stafford, 1991). Cell cultures also provide effective systems for elucidating the biochemical aspects of secondary product formation, or for exploring the physiological properties of intermediates in biosynthetic pathways. Cell cultures may accumulate different secondary metabolites from those found in vivo, or may produce insignificant quantities of some components (Nawa et al., 1993; Mori et al., 1993; Wilson, 1990). In other cases, product yields and/or quality traits may be enhanced through production by tissue culture (Cormier and Do, 1993; Crouch et al., 1993). Manipulation of the physical and chemical microenvironments can influence both the quality and yield of natural products (Callebaut et al., 1990; Do and Cormier, 1991).

Anthocyanin production has been reported in cell cultures of edible materials like grapes (Yamakawa et al., 1983), sweet potato (Nozue et al., 1987), carrot (Ozeki and Komamine, 1985), strawberry (Hong et al., 1989; Mori et al., 1993), and rabbiteye blueberry (Nawa et al., 1993). Cranberry has been cultured in vitro for micropropagation (Marcotrigiano and McGlew, 1991) and genetic transformation (Serres et al., 1992), but in vitro pigment production has not been reported. Our objective was to compare anthocyanins derived from cranberry fruits in vivo, vegetative parts, and callus cultures derived from different parts of the plant. The expression of other flavonoids like flavonols and proanthocyanidins, in vivo and in vitro were also investigated and the activity of phenylalanine ammonia-lyase, one of the early enzymes in the flavonoid biosynthetic pathway, was

Authors Madhavi and Smith are with the Horticulture Dept., 1201 $S$. Dorner Drive, Univ. of Illinois, Urbana, IL 61801. Author BerberJimenez is with the Food Science Dept., 1208 W. Pennsylvania Ave., Univ. of Illinois, Urbana, IL 61801. Address inquiries to Dr. M.A.L. Smith. determined to help elucidate the anthocyanin biosynthetic potential of the cultures.

\section{MATERIALS \& METHODS}

CRANBerRy 'Stevens' FrutTs were obtained from the Blueberry and Cranberry Research Center, Rutgers University, and stored at $-20^{\circ} \mathrm{C}$ until assayed. Plants of the same genotype were maintained in the greenhouse and as shoot cultures in WPM medium (Lloyd and McCown, 1981) supplemented with 0.98 $\mu \mathrm{M}$ 6- $(\gamma, \gamma$-dimethylallylamino $)$ purine.

\section{Callus initiation and pigment production}

Stem segments $(1 \mathrm{~cm})$ and leaves from $8 \mathrm{wk}$ old shoot cultures and the mesocarp tissue of mature fruits were used for callus initiation. Explants were placed in the dark at $25^{\circ} \mathrm{C}$ on a callus induction medium (modified Gamborg's medium, Gamborg et al,, 1968) with $8 \mathrm{mM} \mathrm{NO}_{3}^{-}$ as $\mathrm{KNO}_{3}, 25 \mathrm{mM} \mathrm{NH}{ }_{4}^{+}$as $\left(\mathrm{NH}_{4}\right)_{2} \mathrm{SO}_{4}, 200 \mu \mathrm{M}$ Fe as FeNa $\mathrm{EDTA}_{2}, 5.37$ $\mu \mathrm{M} \alpha$-naphthaleneacetic acid, $0.45 \mu \mathrm{M}$ 2,4-dichlorophenoxyacetic acid, $2.32 \mu \mathrm{M}$ kinetin, $100 \mathrm{mg} / \mathrm{L}$ PVP (Sigma Chemical Co., St. Louis, MO), $10 \%$ coconut water, $2 \%$ sucrose, and $0.7 \%$ agar. Subcultures were derived at $3 \mathrm{wk}$ intervals. After the fourth subculture, callus colonies were transferred to pigment production medium containing no coconut water, reduced $\mathrm{NO}_{3}^{-}(2 \mathrm{mM})$ and increased sucrose $(5 \%)$ and held under a photosynthetic photon flux of $55 \mu \mathrm{mol} \mathrm{m} \mathrm{m}^{-2} \mathrm{~s}^{-1}$. Time course experiments for anthocyanin production were done both at $8 \mathrm{mM}$ and $2 \mathrm{mM} \mathrm{NO}_{3}^{-}$ levels in the production medium. Total anthocyanins were estimated by the method of Francis (1982). Results are averages of two replicates.

\section{HPLC analysis of anthocyanins and anthocyanidins}

The samples were extracted in $1 \%(\mathrm{v} / \mathrm{v}) \mathrm{HCl}$ methanol $(1: 10 \mathrm{w} / \mathrm{v})$ overnight at $4^{\circ} \mathrm{C}$ and the extracts after filtration were evaporated to dryness at $30^{\circ} \mathrm{C}$ with a Buchi rotary evaporator (Switzerland). The residue was dissolved in water and extracted with ethyl acetate $(1: 3 \mathrm{v} / \mathrm{v})$ three times. The aqueous fraction was evaporated to remove residual ethyl acetate and adsorbed onto an activated OnGuard-RP Sep-Pak cartridge (Dionex, CA). The cartridge was washed with water and anthocyanins were eluted with $0.01 \% \mathrm{HCl}$ in methanol. The extract was evaporated, redissolved in $10 \%$ formic acid, and filtered through a $0.2 \mu \mathrm{m}$ filter membrane (Phenomenex, CA). HPLC was performed using a Hitachi L6200A Intelligent Pump (Tokyo, Japan), a Hitachi Diode Array Detector (Tokyo, Japan), and a Rheodyne (Cotiati, CA) 7125 Injector. The column was a YMC-Pack ODS-AM $(250 \times 4.6 \mathrm{~mm}, 5 \mu)$ connected to a YMC-Pack S5 120A ODS-AM guard column. Solvents were $10 \%$ formic acid $(A)$ and $100 \%$ acetonitrile $(B)$ at $1 \mathrm{~mL} / \mathrm{min}$. The elution profile was $0-4 \mathrm{~min}, 10-14 \% \mathrm{~B}$ in $\mathrm{A} ; 4-10 \mathrm{~min}, 14-16 \% \mathrm{~B}$ in $\mathrm{A} ; 10-20 \mathrm{~min}$, $16-18 \% \mathrm{~B}$ in $\mathrm{A} ; 20-25 \mathrm{~min}, 18-30 \% \mathrm{~B}$ in $\mathrm{A}$. Absorbance was monitored at $520 \mathrm{~nm}$. Peak identification was done using authentic standards isolated from the fruit and other known sources.

Anthocyanins from fruit extract and callus cultures were subjected to acid hydrolysis in $2 \mathrm{~N} \mathrm{HCl}$ :methanol (1:1) for $30 \mathrm{~min}$ as described by Markham (1982). Anthocyanidins derived from acid hydrolysis were analysed using a Whatman Partisil ODS-3 $(250 \times 4.6 \mathrm{~mm}, 5 \mu)$ column connected to a YMC-Pack S5 120A ODS-AM guard column. Solvents were $10 \%$ formic acid (A) and $100 \%$ acetonitrile (B). Separation was obtained by an isocratic elution of $20 \% \mathrm{~B}$ in $\mathrm{A}$ at $1 \mathrm{~mL} / \mathrm{min}$.

\section{HPLC analysis of other flavonoids}

The ethyl acetate-extractable fraction was washed with water, passed through anhydrous sodium sulfate to remove residual moisture and evap- 


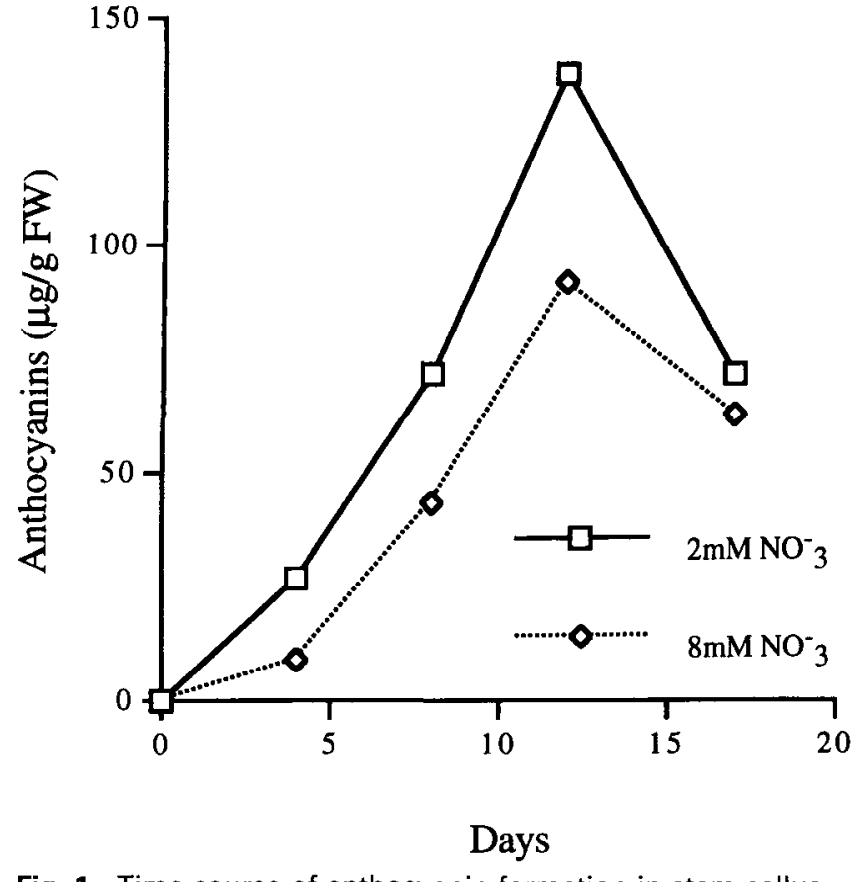

Fig. 1-Time course of anthocyanin formation in stem callus.
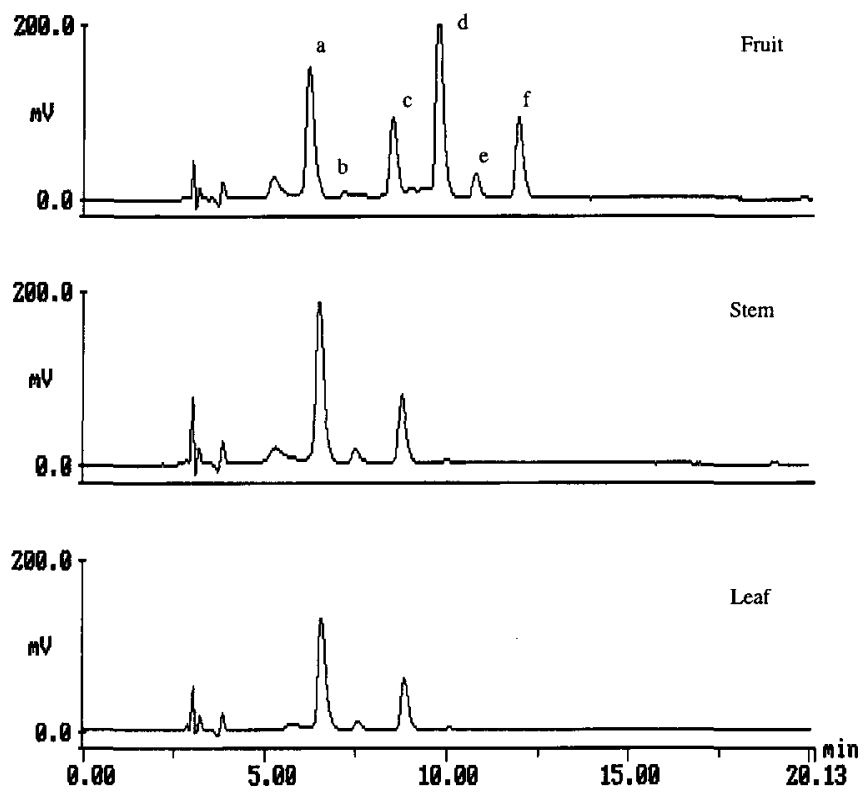

Fig. 2-Reverse phase HPLC profile of anthocyanins in cranberry fruit and vegetative tissues. Peak identification: a. Cyanidin 3-galactoside, b. Cyanidin 3-glucoside, c. Cyanidin 3-arabinoside, d. Peonidin 3-galactoside, e. Peonidin 3-glucoside, $f$. Peonidin 3-arabinoside

\section{RESULTS}

anol. Conditions for HPLC analysis were similar to anthocyanin analysis with an altered elution profile: $0-4 \mathrm{~min}, 10-14 \% \mathrm{~B}$ in $\mathrm{A} ; 4-10 \mathrm{~min}, 14-$ $18 \% \mathrm{~B}$ in $\mathrm{A} ; 10-20 \mathrm{~min}, 18-30 \% \mathrm{~B}$ in $\mathrm{A} ; 20-30 \mathrm{~min}, 30-50 \% \mathrm{~B}$ in $\mathrm{A}$; $30-35 \mathrm{~min}, 50-100 \% \mathrm{~B}$ in $\mathrm{A}$. Absorbance was monitored at $280 \mathrm{~nm}$.

\section{Proanthocyanidins}

Proanthocyanidins were estimated as anthocyanidins by the method of Nawa et al. (1993). Samples were repeatedly extracted in cold $\left(4^{\circ} \mathrm{C}\right) 1 \%$ $\mathrm{HCl}$ methanol to remove all pigments. The residue after pigment extraction was suspended in $1 \% \mathrm{HCl}$ methanol $(1: 10 \mathrm{w} / \mathrm{v})$, incubated overnight at $50^{\circ} \mathrm{C}$ then filtered. Absorbance was measured at $535 \mathrm{~nm}$ and expressed as absorbance units (A.U.)/g fresh weight (FW). Results are averages of two replicates.

\section{Phenylalanine ammonia-lyase (PAL) activity}

Samples were ground in liquid $\mathrm{N}_{2}$ to a fine powder and suspended in $-20^{\circ} \mathrm{C}$ acetone for $15 \mathrm{~min}$. The precipitate was collected by filtration, washed with acetone and dried at room temperature $\left(25^{\circ} \mathrm{C}\right)$. Acetone powders were extracted with $0.1 \mathrm{M}$ borate buffer, $\mathrm{pH} 8.8$, containing $20 \mathrm{mM} 2$-mercaptoethanol, $0.5 \mathrm{~g}$ dry Polyclar $\Lambda \mathrm{T}$ (ISP Technologies, Inc., Wayne, NJ), and 0.5g dry Amberlite XAD-4 (Sigma Chemical Co., St. Louis, MO). The extract was pressed through cheesecloth and centrifuged cold $\left(4^{\circ} \mathrm{C}\right)$ at $10,000 \mathrm{rpm}$ for $20 \mathrm{~min}$. The supernatant was dialyzed overnight $\left(4^{\circ} \mathrm{C}\right)$ in $0.1 \mathrm{M}$ borate buffer, $\mathrm{pH} 8.8$, containing $20 \mathrm{mM} \mathrm{2-}$ mercaptoethanol. The dialyzate was centrifuged cold $\left(4^{\circ} \mathrm{C}\right)$ at $10,000 \mathrm{rpm}$ for $10 \mathrm{~min}$ and used for assay.

Enzyme activity was measured by the method of Havir and Hanson (1971). The assay mixture contained $0.5 \mathrm{~mL}$ of $0.2 \mathrm{M}$ borate buffer, $\mathrm{pH}$ $8.8,0.2 \mathrm{~mL}$ enzyme solution, and water to a final volume of $2.8 \mathrm{~mL}$. Control assays contained buffer or water in place of enzyme solution or $\mathrm{L}$-phenylalanine. The mixture was incubated at $30^{\circ} \mathrm{C}$ for $30 \mathrm{~min}$. The reaction was initiated by addition of $0.2 \mathrm{~mL}$ of $0.1 \mathrm{M}$ L-phenylalanine. The absorbance of the reaction mixtures and blanks was recorded at 280 $\mathrm{nm}$ at $15 \mathrm{~min}$ intervals using a Beckman DU-65 spectrophotometer (Fullerton, CA) with a temperature controlled auto- 6 sampler, at $30^{\circ} \mathrm{C}$. One unit of activity was defined as the amount of enzyme catalyzing the formation of $1 \mu$ mole cinnamate $/ \mathrm{min}$ at $30^{\circ} \mathrm{C}$. Results are averages of three replicates. Protein was estimated by Bradford's method (Bradford, 1976).

\section{Callus cultures and anthocyanin formation}

A yellow colored callus was obtained in the dark in callus induction medium. Modification of Gamborg's medium was necessary to enhance growth and reduce callus culture browning. An increase in $\mathrm{NH}_{4}^{+}$level and a decrease in $\mathrm{NO}_{3}^{-}$level with a 3:1 $\mathrm{NH}_{4}^{+}$and $\mathrm{NO}_{3}^{-}$ratio was essential to reduce browning and induce friability of the cultures. Addition of coconut water enhanced callus growth. On transferring cultures to light in the production medium, intense pigmentation was observed. Maximum anthocyanin formation was observed by day 12 (Fig. 1) after transferring cultures to light. The level of $\mathrm{NO}_{3}^{-}$in the production medium had an effect on anthocyanin concentration. At the $2 \mathrm{mM}$ level, a higher anthocyanin accumulation was observed on all days.

\section{Anthocyanins and anthocyanidins}

Reverse phase HPLC chromatograms of the anthocyanins in vivo from fruits and from stem and leaves (Fig. 2) showed fruit extract had four major pigments comprised of cyanidin and peonidin 3-galactosides and 3-arabinosides. Cyanidin and peonidin 3-glucosides were the minor pigments. Stems and leaf tissucs from the greenhouse and shoot culturcs had only cyanidin 3-galactoside, 3-glucoside, and 3-arabinoside, with the glucoside as the minor fraction. The anthocyanin profiles (Fig. 3) showed simple profiles consisting of mainly cyanidin 3-galactoside, 3glucoside, and 3-arabinoside in all pigmented callus cultures regardless of source of explant. Anthocyanins were not detected in dark grown callus cultures. On acid hydrolysis of the anthocyanins, cyanidin and peonidin were the aglycones in the fruit extract and cyanidin was the only aglycone in the callus cultures (Fig. 4).

\section{Proanthocyanidins}

Incubation of the tissue residues in methanol- $\mathrm{HCl}$ at $50^{\circ} \mathrm{C}$ for $18 \mathrm{hr}$ resulted in the release of intense red pigments from all samples with absorbance maximum at $535 \mathrm{~nm}$. The pigments were not extractable by cold methanol-HCl. The A.U./g FW from anthocyanins and anthocyanidins derived from proantho- 


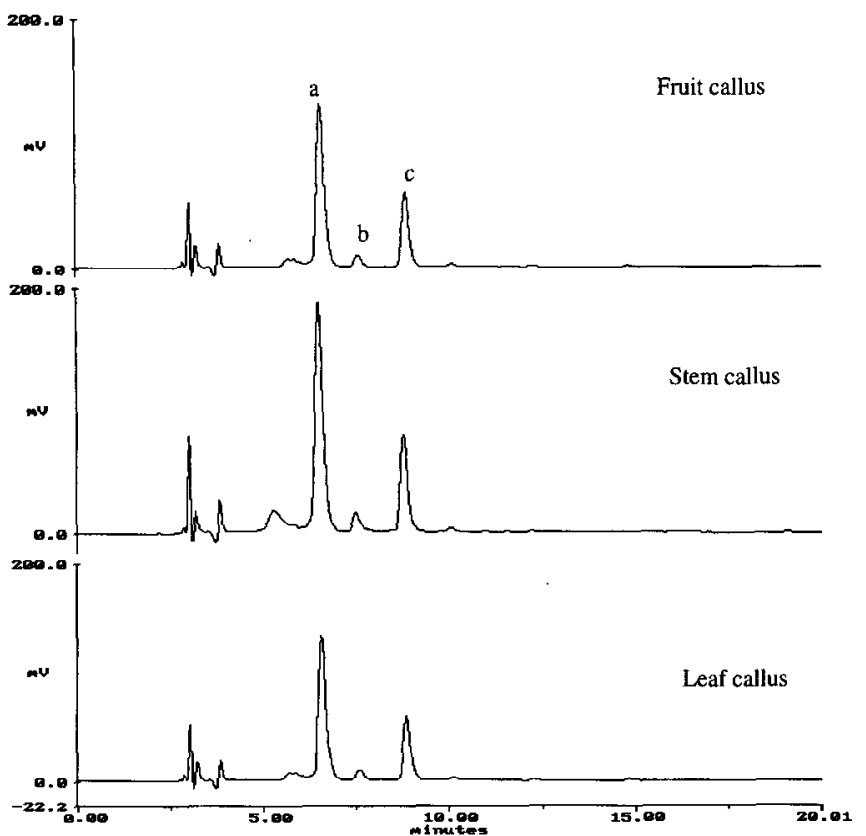

Fig. 3-Reverse phase HPLC profile of anthocyanins in cranberry callus cultures. Peak identification: a. Cyanidin 3-galactoside, b. Cyanidin 3-glucoside, c. Cyanidin 3-arabinoside

cyanidins in vivo and in vitro (Table 1) showed fruit extract had higher absorption due to anthocyanins whereas extracts of vegetative explants had a very high absorption due to proanthocyanidins. Fruit callus culture extracts had a very low level of anthocyanins and a higher proanthocyanidin absorption. Pigmented callus cultures from stems and leaves had a higher anthocyanin level and a lower absorption due to proanthocyanidins. Callus cultures in the dark accumulated proanthocyanidins at comparable levels to cultures under light.

\section{Other flavonoids}

Peaks from reverse phase HPLC chromatograms of the ethyl acetate-extractable fractions were classified tentatively into two major groups of compounds based on spectral properties. Group 1 was comprised of compounds absorbing mainly at 270-290 $\mathrm{nm}$, indicative of catechins, flavanones, and those absorbing at $280-330 \mathrm{~nm}$, indicative of cinnamic acids. Group 2 was comprised of compounds absorbing at $280,350-375 \mathrm{~nm}$, indicative of flavonols and their glycosides (Table 2). Fruit extract had a higher percentage of group 2 compounds whereas vegetative explants had a higher percentage of group 1 compounds. Pigmented callus cultures from vegetative explants were similar to explants. However, pigmented fruit callus culture had a much lower percentage of group 2 compounds in contrast to the fruit. Dark-grown callus cultures (colorless) had mainly group 1 compounds, and flavonols and their derivatives were not detected (Fig. 5).

\section{Phenylalanine ammonia-lyase activity}

Sample enzyme activity (Table 3 ) showed dark-grown callus cultures had a lower activity. A threefold increase in activity was observed on exposure to light. However, all cultures had lower levels of activity compared to explants.

\section{DISCUSSION}

OUR MAIN OBJECTIVE was to establish and compare cell cultures from different parts of cranberry plants for their potential to accumulate anthocyanins and other flavonoids and to determine the influence of explant source on composition of in vitro prod-

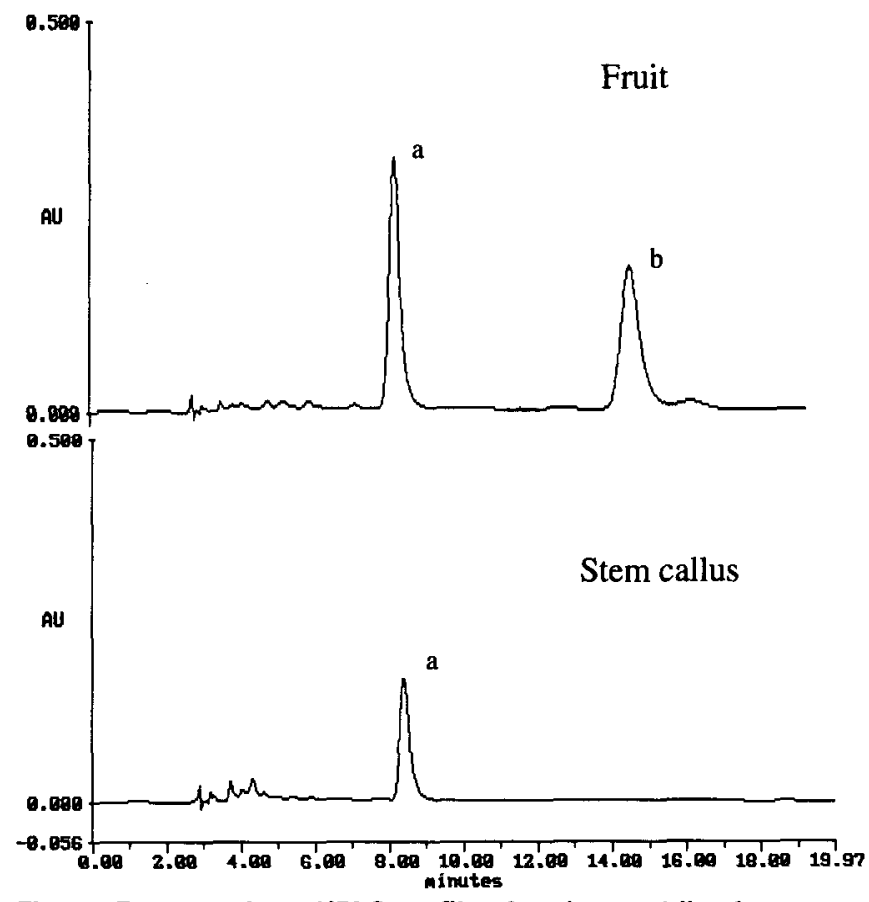

Fig. 4-Reverse phase HPLC profile of anthocyanidins from cranberry fruit (in vivo) and stem callus (in vitro). Peak identification: a. Cyanidin, b. Peonidin.

Table 1-Absorbance due to anthocyanins and proanthocyanidins in cranberry in vivo and in vitro

\begin{tabular}{lcc}
\hline Source & $\begin{array}{c}\text { Anthocyanins } \\
\text { (A.U./g FW) }\end{array}$ & $\begin{array}{c}\text { Proantho- } \\
\text { cyanidins } \\
\text { (A.U./g FW) }\end{array}$ \\
\hline Fruit (in vivo) & 29.62 & 21.46 \\
Stem (from microcultures) & 1.04 & 82.59 \\
Leaf (from microcultures) & 0.61 & 85.31 \\
Stem Callus (colored) & 2.52 & 27.39 \\
Stcm Callus (colorlcss) & 0.112 & 23.5 \\
Leaf Callus (colored) & 3.31 & 49.2 \\
Fruit Callus (colored) & 2.19 & 57.31 \\
Fruit Callus (colorless) & 0.254 & 59.5
\end{tabular}

Table 2-Percentage of total peak area of compounds in ethyl acetate-extractable fraction from cranberry in vivo and in vitro

\begin{tabular}{lcc} 
& Absorbance & Absorbance \\
& $270-290 \mathrm{~nm}^{\mathrm{a}}$ & 280, \\
Source & $280-320 \mathrm{~nm}^{\mathrm{b}}$ & $350-380 \mathrm{~nm}^{\mathrm{c}}$ \\
\hline
\end{tabular}

Fruit (in vivo) 280-320 $\mathrm{nm}^{2}$

66.2

Stem (from microcultures)

Leaf (from microcultures)

Stem Callus (colored)

Stem Callus (colorless)

Leaf Callus (culored)

Fruit Callus (colored)

Fruit Callus (colorless)

$\begin{array}{ll}33.7 & 66.2 \\ 68.1 & 31.9\end{array}$

$\begin{array}{ll}70.1 & 29.9\end{array}$

$\begin{array}{ll}79.8 & 20.2\end{array}$

79.8

100

73.0

20.2

27

7.0

a Compounds with absorption spectra of catechins, flavanones

b Compounds with absorption spectra of cinnamic acids

c Compounds with absorption spectra of flavonols and their glycosides

ucts. Anthocyanins in cranberry fruits are well characterized and our results confirmed previous reports (Hong and Wrolstad, 1990; Fuleki and Francis, 1967). Callus cultures resembled other anthocyanin producing systems in many properties. Callus cultures accumulated anthocyanins only on exposure to light. Anthocyanin level was lower as in other cell culture systems like rabbiteye blueberry (Nawa et al., 1993). Higher sucrose levels and lower nitrate levels enhanced anthocyanin accumulation in parallel with other cell culture systems like grapes (Do and Cormier, 1991; Hirasuna et al., 1991). Previous studies in our lab- 

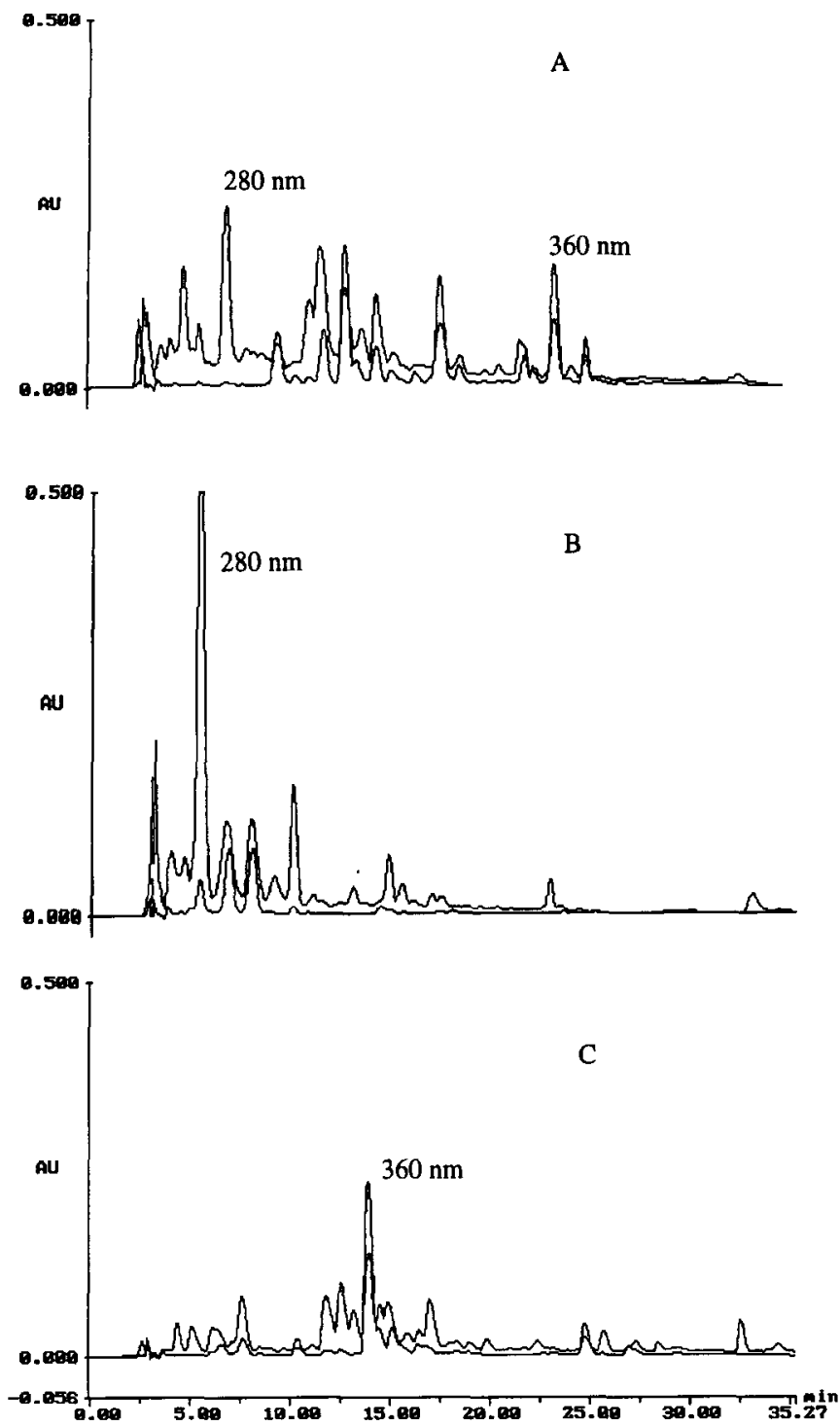

Fig. 5-Reverse phase HPLC profile of the ethyl acetate-extractable fraction. A. Stem, B. Stem Callus (colorless), C. Stem Callus (colored).

Table 3-Phenylalanine ammonia-lyase activity from cranberry in vivo and in vitro

\begin{tabular}{|c|c|c|}
\hline Source & $\begin{array}{c}\text { Units } \times \\
10^{-3} / \mathrm{g} \mathrm{FW}\end{array}$ & $\begin{array}{c}\text { Units } \times \\
10^{-3} / \mathrm{mg} \text { protein }\end{array}$ \\
\hline Stem (from microcultures) & 58.21 & 18.0 \\
\hline Leaf (from microcultures) & 42.98 & 5.4 \\
\hline Stem Callus (colored) & 4.69 & 4.27 \\
\hline Stem Callus (colorless) & 0.873 & 1.56 \\
\hline Leaf Callus (colored) & 4.60 & 3.96 \\
\hline Leaf Callus (colorless) & 1.89 & \\
\hline
\end{tabular}

oratory have indicated that higher sucrose levels were necessary to induce anthocyanin production in cranberry cultures (Madhavi et al., 1993). Total anthocyanin levels increased from 0$3.0 \%$ on increasing sucrose levels from $2-5 \%$ in the production medium. Anthocyanin profiles were simpler, similar to other in vitro systems like rabbiteye blueberry (Nawa et al., 1993) and grapes (Yamakawa et al., 1983). The decline in anthocyanin concentration after 12 days could be mainly due to depletion of nutrients in the culture medium and has been reported in rabbiteye blueberry cell cultures (Nawa et al., 1993). It was interesting to note that fruit callus had low levels of anthocyanins and a similar anthocyanin profile to callus cultures derived from vegetative explants, indicating that fruit callus was physiologically distinct from differentiated fruit tissue.

Qualitative and quantitative differences in anthocyanin accumulation in fruits in vivo and callus cultures in vitro could be due to the physiological nature of explant tissues used for callus induction. In cranberry fruits, anthocyanins are localized in the epidermis and the fruit callus culture was derived from mesocarp tissue, devoid of anthocyanins. Vegetative tissues both in the greenhouse and microculture had traces of anthocyanins and qualitatively only cyanidin glycosides. Peonidins differ from cyanidins by a single methyl group substitution at the 3 ' position in the B ring and are generally considered to be derived from cyanidins by a methylation reaction. Methylation reactions in the flavonoid biosynthetic pathway are catalysed by specific $O$ methyltransferases with S-adenosyl-L-methionine as the methyl donor (Poulton, 1981). O-methyltransferases specific for glucosylated and acylated anthocyanidins have been demonstrated in Petunia hybrida (Jonsson et al., 1982).

No information is available on properties of methyltransferases in cranberries. Our results, however, indicated that the callus cultures and vegetative tissues may lack methyltransferases specific for anthocyanins or the methyl donor. In general, the metabolic constraints physiological regulations operative in the callus cultures seemed to be similar to the source explants. Our results also indicated that some constraints could be overcome by manipulation of cultural conditions. Anthocyanin accumulation was lower in vitro as compared to the fruit extract but was clearly higher than explant tissues (Table 1). Establishment of suspension cultures and use of selection protocols may help in developing intensely pigmented cell lines as with Vitis hybrida (Yamakawa et al., 1983), Ajuga reptans (Callebaut et al., 1988), and Daucus carota (Kinnersley and Dougall, 1980).

The ethyl acetate-extractable fraction was analysed mainly to get an indication of the presence of flavonoids other than anthocyanins. The chromatograms were monitored at $280 \mathrm{~nm}$ since all compounds absorbed at that wavelength and the area percentage was also expressed in the same wavelength (Table 2). This slightly underestimates flavonols and their derivatives which absorb more strongly at $350-370 \mathrm{~nm}$. However, this method of representation based on spectral properties gave a good indication of differences in vivo and in vitro. Cranberry fruits are a rich source of flavonols (Bilyk and Sapers, 1986) and our results indicated a higher percentage of flavonols. Callus cultures from vegetative explants were similar to the explants and had a higher percentage of cinnamic acids and catechins. Fruit callus differed from fruit in that it had a lower percentage of flavonols. Callus cultures accumulated flavonols only on exposure to light (Fig. 5).

Proanthocyanidins are condensation products of monomeric leucoanthocyanidins and catechins and include dimers, oligomers, and polymers. Those with molecular weights $>7000$ become insoluble in organic and aqueous solvents (Czochanska et al., 1979; Haslam, 1980). Proanthocyanidins extractable in cold organic solvents have been reported in cranberry fruits (Wang et al., 1978; Foo and Porter, 1981). We have demonstrated the presence of insoluble proanthocyanidins both in vivo and in vitro indirectly by hydrolysis in $\mathrm{HCl}$ methanol. In vivo, fruits seemed to have a low level of insoluble proanthocyanidins which could be mainly related to the degree of fruit ripening (Haslam, 1977). In vitro, callus cultures from vegetative explants showed lower accumulation of insoluble proanthocyanidins as compared to explants. Fruit callus again differed from fruit and had a higher level of insoluble proanthocyanidins and was similar to cultures from vegetative explants. Light was not a limiting factor for proanthocyanidin accumulation in our cultures (Table 1). Light independent accumulation of high molecular weight proanthocyanidins has been reported in other cell culture systems like Cryptomeria japonica (Ishikura and Teramoto, 1983), Fagopyrum esculentum (Moumou et al., 1992) and Vaccinium ashei (Nawa et al., 1993). Cultural conditions also reportedly influence 
the accumulation of proanthocyanidins in cell cultures (Zaprometov, 1988). Proanthocyanidins and anthocyanins share common intermediates in the biosynthetic pathway. Hence, inhibition of proanthocyanidin synthesis by manipulating cultural conditions may enhance anthocyanin accumulation.

Phenylalanine ammonia-lyasc catalyzes the formation of trans-cinnamic acid, the first phenylpropanoid, by the deamination of L-phenylalanine and provides the link between primary metabolism and the phenylpropanoid pathways (Ebel and Hahlbrock, 1982). The enzyme may also have a regulatory effect in anthocyanin accumulation (Hahlbrock, 1981). Sapers et al. (1987) demonstrated PAL activity in the skin of cranberry fruits and reported that the activity did not correlate with anthocyanin accumulation. Our studies indicated that the observation could be extended to vegetative parts of the plant. In vitro, dark grown cultures had a basal level of activity which was enhanced by illumination (Table 3). Exposure to light induced the formation of anthocyanins and flavonols. PAL and other enzymes in the flavonoid biosynthetic pathway are highly light inducible (McClure, 1975) and our results confirmed this. However, cultures also accumulated proanthocyanidins in the absence of light, which implied the synthesis of dihydroflavonols and leucoanthocyanidins, common intermediates for anthocyanins, flavonols, and proanthocyanidins in the biosynthetic pathway. This indicated that the increase in PAL activity could be responsible for an enhanced precursor pool in the biosynthetic pathway.

\section{REFERENCES}

Bilyk, A. and Sapers, G.M. 1986. Varietal differences in the quercetin kaempferol, and myricetin contents of highbush blueberry, cranberry, and thornless blackberry fruits. J. Agric. Food Chem. 34: 585-588.

Bradford, M.M. 1976. A rapid and sensitive method for the quantitation of microgram quantities of protein utilizing the principle of protein-dye binding. Anal. Biochemistry 72: 248-254.

Callebaut, A., Hendrickx, G., Voets, A.M., and Perwez, C. 1988. Production of anthocyanins by cell cultures of Ajuga reptans. Med. Fac. Landbouww Rijksuniv Gent. 53: 1713-1715.

Callebaut, A., Hendrickx, G., Voets, A.M., and Motte, J.C. 1990. Anthocya nins in cell cultures of Ajuga reptans. Phytochemistry $29: 2153-2158$.

Cormier, F. and Do, C.B. 1993. Vitis vinifera L. (Grapevine): In Vitro Pro duction of Anthocyanins, Biotechnology in Agriculture and Forestry, Vol. 24, Y.P.S. Bajaj (Ed.), p. 373-386. Springer-Verlag, Berlin Heidelberg.

Crouch, N.R., Van Staden, L.F., Drewes, F.E., and Meyer, H.J. 1993. Accumulation of cyanidin 3-glucoside in callus and cell cultures of Oxalis reclinata. J. Plant Physiol. 142: 109-111.

Czochanska, Z., Foo, L.Y. Newman, R.H., Porter, L.J., Thomas, W.A., and Jones, W.T. 1979. Direct proof of a homogeneous polyflavan-3-ol structure for polymeric proanthocyanidins. J. Chem. Soc. Chem. Commun. 375-377. for polymeric proanthocyanidins. J. Chem. Soc. Chem. Commun. 375-377.
Do, C.B. and Cormier, F. 1991. Effects of low nitrate and high sugar concentrations on anthocyanin content and composition in grape (Vitis vinifera L.) cell suspension. Plant Cell Reports 9: 500-504.

Ebel, J. and Hahlbrock, K. 1982. Biosynthesis. In The Flavonoids: Advances in Research, J.R. Harborne and T.J. Mabry (Ed.), p. 641-679. Chapman and Hall, New York.

Foo, L.Y. and Porter, L.J. 1981. The structure of tannins of some edible fruits. J. Sci. Food Agric. 32: $711-716$.

Francis, F.J. 1982. Analysis of anthocyanins. In Anthocyanins as Food Col ors, P. Markakis (Ed.), p. 181-207. Academic Press, New York.

Fuleki, T. and Francis, F.J. 1967. The co-occurrence of monoglucosides and monogalactosides of cyanidin and peonidin in the American cranberry, Vaccinium macrocarpon. Phytochemistry 6: 1705-1708

Gamborg, O.L., Miller, R.A., and Ojima, K. 1968. Nutrient requirements of suspension cultures of soybean root cells. Exp. Cell Res. 50: 151-158.

Hahlbrock, K. 1981. Flavonoids. In The Biochemistry of Plants, Vol. 7, Secondary Plant Products, P.K. Stumpf and E.E. Conn (Ed.), p. 425-456. Academic Press, New York.

ademic Press, New York.
Haslam, E. 1977. Symmetry and promiscuity in procyanidin biochemistry. Phytochemistry 16: 1625-1640.

Haslam, E. 1980. In vino veritas: Oligomeric procyanidins and the aging of red wines. Phytochemistry 19: 2577-2582.

Havir, E.A. and Hanson, K.R. 1971. L-Phenylalanine ammonia-lyase (potato tubers), Methods in Enzymology 17a: 575-578.
Hirasuna, T.J., Shuler, M.L., Lackney, V.K., and Spanswick, R.M. 1991. Enhanced anthocyanin production in grape cell cultures. Plant Science 78 $107-120$.

Hong, V. and Wrolstad, R.E. 1990. Use of HPLC separation/photodiode array detection for characterization of anthocyanins. J. Agric. Food Chem. 38: 708-715.

Hong, Y.C., Read, P.E., Harlander, S.K., and Labuza, T.P. 1989. Development of a tissue culture system from immature strawberry fruits. J. Food Sci. 54: 388-392

Ilker, R. 1987. In vitro pigment production: an alternative to color synthesis. Food Technol 41(4): 70-72.

Ishikura, N. and Teramoto, S. (1983). Procyanidins and catcchin from callus and cell suspension cultures of Cryptomeria japonica. Agric. Biol. Chem. 47; $421-423$.

Jonsson, L.M.V., Aarsman, M.E.G., Schram, A.W., and Bennink, G.J.H. 1982. Methylation of anthocyanins by cell-free extracts of flower buds of Petunia hybrida. Phytochemistry 21: 2457-2459.

Kinnersely, A.M. and Dougall, D.K. 1980. Increase in anthocyanin yield from wild-carrot cell cultures by a selection system based on cell-aggregate size. Planta 149: 200-204

Lloyd, G. and McCown, B.H. 1981. Commercially-feasible micropropagation of mountain laurel, Kalmia latifolia by use of shoot tip culture. Proc. Int. Plant Prop. Soc. 30: 421-427.

Madhavi, D.L., Smith, M.A.L., and M.D. Berber-Jimenez, M.D. 1993. Anthocyanins from cell cultures of cranberry. Proceedings of the First Interthocyanins from cell cultures of cranberry. Proceedings of the First interAmherst, MA, 283-286.

Markham, K.R. 1982. Techniques of Flavonoid Identification. Academic Press, New York.

Marcotrigiano, M. and McGlew, S.P. 1991. A two-stage micropropagation system for cranberries. J. Amer. Soc. Hort. Sci. 116: 911-916.

McClure, J.W. 1975. Physiology and Functions of Flavonoids. In The Flavonoids, J.B. Harborne, T. Mabry, and H. Mabry (Ed.), p. 970-1055. Chapman and Hall, London.

Mori, T. Sakurai, M Shigeta, J Yoshida, K, and Kondo, T, 1993. ForMori, T., Sakurai, M., Shigeta, J., Yoshida, K., and Kondo, T. 1993. Forberry plants. J. Food Sci. 58: 788-792.

Moumou, Y., Trotin, F., Vasseur, J., Vermerrsch, G., Guyon, R., Dubois, J., and Pinkas, M. 1992. Procyanidin production by Fagopyrum esculentum callus culture. Planta Med. 58: 516-519.

Nawa, Y., Asano, S., Motoori, S., and Ohtani, T. 1993. Production of anthocyanins, carotenoids, and proanthocyanidins by cultured cells of rabbiteye blueberry (Vaccinium ashei Reade). Biosci. Biotech. Biochem. 57: 770-774

Nozue M Kawai, J and Yoshitama, K 1987. Selection of a high anthocyanin-producing cell line of sweet potato cell cultures and identification of pigments. J. Plant Physiol. 129: 81-88.

Ozeki, Y. and Komamine, A. 1985. Effects of inoculum density, zeatin, and sucrose on anthocyanin accumulation in a carrot suspension culture. Plant Cell Tissue Org. Cult. 5: 45-53.

Poulton, E.J. (1981). Transmethylation and demethylation reactions in the metabolism of secondary plant products. In The Biochemistry of Plants, Vol. 7, Secondary Plant Products, P.K. Stumpf and E.E. Conn (Ed.), p.

667-723. Academic Press, New York.
Sapers, G.M., Matulaitis, R.M., and Beck, J.A. (1987). Detection of phenyl-

apers, G.M., Matulaitis, R.M., and Beck, J.A. (1987). Detection of phenyl-
alanine ammonia-lyase activity in the skin of blueberry and cranberry fruits. J. Food Sci. 52: 155-158.

Serres, R., Stang, D., McCabe, D., Russel, D., Mahr, D., and McCown, B.H. 1992. Gene transfer using electric discharge particle bombardment and recovery of transformed cranberry plants. J. Amer. Soc. Hort. Sci. 117 174-180.

Shuler, M.T., Hirasuna, T., Prince, C., and Bringi, V. 1990. Bioreactor considerations for producing flavors and pioments from plant tissue culture. In Biotechnology and Food Process Engineering, $\mathrm{H}$. Schwartzberg and $\mathrm{M}$ In Biotechnology and Food Process Engineering, $H$.

Rao (Ed.), p. 45-65. Marcel Dekker, Inc., New York.
Stafford, A. 1991. The manufacture of food ingredients using plant cell and tissue cultures. Trends in Food Sci. Tech. 2: 116-122.

Wang, P.L., Du, C.T., and Francis, F.J. 1978. Isolation and characterization of polyphenolic compounds in cranberries. J. Food Sci. 43: 1402-1404.

Wilson, G. 1990. Screening and selection of cultured plant cells for increased yields of secondary metabolites. In Plant Cell Line Selection, P.J. Dixon (Ed.), p. 187-213. VCH, Weinheim.

Yamakawa, T., Ishida, K., Kato, S., Kodama, T., and Minoda, Y. 1983. For mation and identification of anthocyanins in culture cells of Vitis sp. Agric. Biol. Chem. 47: 997-1001.

Zaprometov, M.N. 1988. Proanthocyanidins and catechins. Ch. 4, in Cell Culture and Somatic Cell Genetics of Plants, Vol. 5, F. Constabel and I.K. Vasil (Ed.), p. 77-88

We thank Dr. N Vorsa, Rutgers Univ-CCook College Blueberry and Cranberry Research Center, for providing cranberry fruits. This research is supported by NRI Competitive Grants Program/USDA (AG Grant No. 92-37500-8145). 